\title{
Human parasites in the Roman World: health consequences of conquering an empire
}

\author{
PIERS D. MITCHELL* \\ Department of Archaeology and Anthropology, University of Cambridge, The Henry Wellcome Building, Fitzwilliam \\ Street, Cambridge CB2 1QH, UK
}

(Received 10 September 2015; revised 25 October 2015; accepted 2 November 2015; first published online 8 Fanuary 2016)

SUMMAR Y

The archaeological evidence for parasites in the Roman era is presented in order to demonstrate the species present at that time, and highlight the health consequences for people living under Roman rule. Despite their large multi-seat public latrines with washing facilities, sewer systems, sanitation legislation, fountains and piped drinking water from aqueducts, we see the widespread presence of whipworm (Trichuris trichiura), roundworm (Ascaris lumbricoides) and Entamoeba histolytica that causes dysentery. This would suggest that the public sanitation measures were insufficient to protect the population from parasites spread by fecal contamination. Ectoparasites such as fleas, head lice, body lice, pubic lice and bed bugs were also present, and delousing combs have been found. The evidence fails to demonstrate that the Roman culture of regular bathing in the public baths reduced the prevalence of these parasites. Fish tapeworm was noted to be widely present, and was more common than in Bronze and Iron Age Europe. It is possible that the Roman enthusiasm for fermented, uncooked fish sauce (garum) may have facilitated the spread of this helminth. Roman medical practitioners such as Galen were aware of intestinal worms, explaining their existence and planning treatment using the humoural theory of the period.

Key words: Ectoparasites, helminths, infectious diseases, latrine, medical history, palaeoparasitology, palaeopathology, Plague of Justinian, protozoa, Rome.

\section{INTRODUCTION}

\section{The Romans}

When a cultural group overruns a large area or territory and spreads its ideas and philosophy, we might see changes in the state of human health as a consequence. The Romans conquered a huge empire and altered the lives of its subjects for centuries. Using changes in the ancient parasites present in the regions under Roman control, this study investigates whether Romanization can be seen to have altered the balance of disease experienced by the people who lived in Europe and the Mediterranean region 2000 years ago.

The city of Rome was traditionally founded in 753 $\mathrm{BC}$, and in $509 \mathrm{BC}$, the Roman Republic was founded (Lintott, 2000). In 31 BC, Augustus became the first Roman Emperor following a series of civil wars (Kershaw, 2013). Imperial Rome reached its greatest extent in the 3rd century $\mathrm{AD}$, when the empire covered all the lands from coastal North Africa, the Near East, southern and western Europe and much of Britain (Fig. 1). While the Western Roman Empire fell in 476 AD with the conquest of Rome, the Eastern Empire with its capital of

* Corresponding author. Department of Archaeology and Anthropology, University of Cambridge, The Henry Wellcome Building, Fitzwilliam Street, Cambridge CB2 1QH, UK. E-mail: pdm39@cam.ac.uk
Constantinople lasted until $1453 \mathrm{AD}$ as the Byzantine Empire (Brownworth, 2009; Stathakopoulos, 2014).

The Roman Empire was a place of great mobility, both voluntary and forced. Soldiers, government officials, merchants and slaves moved all over the empire, and Rome itself was a major draw for the ambitious (Handley, 2011). We might potentially find evidence for spread of people with infections if we were to find parasites, endemic in one part of the empire, in a region where their life cycle would make an endemic focus of disease impossible. While the process of 'Romanization' is debated, the Romans were well-known for bringing their ideas about literature, engineering, culture, cuisine, religion and hygiene wherever they ruled (Pitts and Versluys, 2015). It is clear from modern research and theoretical modelling that good sanitation should have improved the health of past populations compared with those who have no sanitation (Mitchell, $2015 a$ ). The spread of Roman knowledge such as clean fresh water in aqueducts, under floor heating for houses, elaborate bathhouses for washing, flushing toilets, civic drains and sewers could in theory have improved the health of the inhabitants (Hobson, 2009; Yegül, 2010; Jansen et al. 2011; Koloski-Ostrow, 2015). In this paper, we will look at the evidence for parasites in Roman times, and by comparing with the situation before and after the Romans we will assess if these 


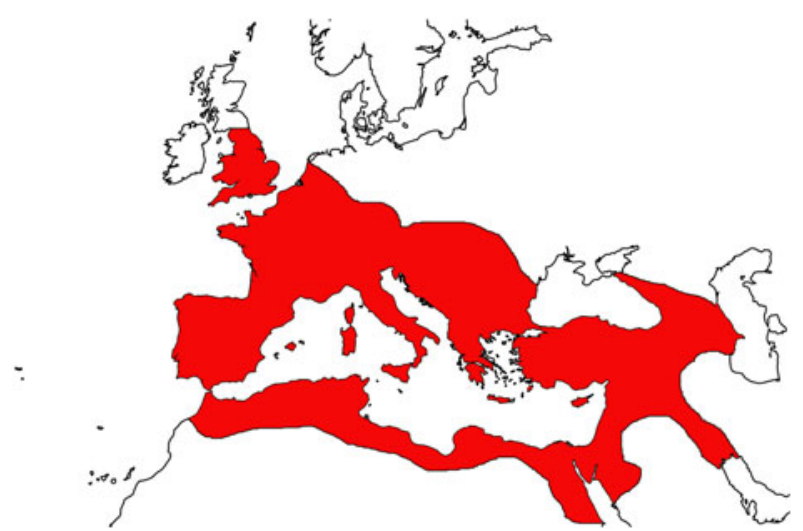

Fig. 1. Map of the Roman Empire at the time of Emperor Trajan, around $117 \mathrm{AD}$.

forms of sanitation seem to have led to a health benefit to those living under Roman rule.

\section{How to study ancient parasites (palaeoparasitology)}

The eggs of most intestinal helminths can be preserved for thousands of years in the right conditions, due to their tough chitinous walls. Human feces in archaeological contexts can be recovered from latrine soil, coprolites (preserved pieces of human feces) and the pelvic soil from burials, where the intestinal contents would have decomposed after death (Reinhard et al. 1986; Warnock and Reinhard, 1992; Araújo et al. 2015; Rácz et al. 2015). While parasite eggs may also be found in ancient rubbish tips, pits or wells, it can sometimes be difficult to differentiate whether these eggs originated from humans rather than animals. For example, whipworm (Trichuris trichiura) in humans is indistinguishable on light microscopy from Trichuris suis in pigs. In such cases, archaeological context and the presence of other parasites unique to animals can help us to determine which origin is more likely (Da Rocha et al. 2006). If coprolites are being analysed, then fecal bile acids and sterols can help identify whether they are from humans, carnivore or herbivore animals (Shillito et al. 2011; Baeten et al. 2012). The ancient DNA of parasites can also be studied to differentiate species that appear similar on microscopy (Leles et al. 2008; Oh et al. 2010). However, this has yet to be undertaken on Roman period parasites.

Identifying ancient parasite eggs does require an understanding of how certain eggs tend to change over archaeological time, known as taphonomy. Roundworm eggs may lose the mammillated outer coat, whipworm may lose the polar plugs and fish tapeworm may lose the operculum. The eggs of some parasite species such as hookworm (Ancylostoma duodenale) and pinworm (Enterobius vermicularis) are particularly fragile and may be easily deformed or lost completely from archaeological samples (Reinhard and Pucu de Araújo,
2014). Research comparing microscopy with genetic techniques suggests that microscopy can underestimate past prevalence for some species, since positive genetic results may occur even when fragile eggs are no longer visible (Jaeger and Iñiguez, 2014). Evidence for species with fragile eggs are most likely to survive in dried coprolites, but while these are commonly found in the Americas they are very rare in Europe. This means that species with a fragile wall may appear to have been rare or absent in Roman times, when they may in fact have been present.

In order to detect parasite eggs from soil sediments we need to transform solid soil to a liquid suspension, known as disaggregation (Reinhard et al. 1986; Anastasiou and Mitchell, 2013a). Then a number of techniques are available to concentrate the eggs, including flotation, sedimentation and microsieves. This concentrate can be mixed with glycerol and viewed with light microscopy. In a coprolite it is possible to count the number of eggs per gram of soil to estimate the degree of parasitism, but in latrines the egg concentration may be effected as much by the amount of rubbish thrown into the latrine as how concentrated the eggs were in the feces of the various users of the facilities. In consequence, in this paper we will look at the geographic distribution of parasite species rather than egg concentrations in order to evaluate change in parasite infection.

The fragile cysts of intestinal amoeba such as Entamoeba histolytica, Giardia duodenalis and Cryptosporidium parvum do not survive well in archaeological soils, and when deformed they are hard to detect with microscopy. A more effective way to detect them has been with enzyme-linked immunosorbent assay (ELISA). This technique employs antibodies that react to the proteins unique to these organisms, regardless of whether the cysts are deformed or broken (Gonçalves et al. 2002, 2004; Frías et al. 2013). Ectoparasites can be detected by fine sieving of soil, and also looking for them on hair combs, mummies or ancient textiles (Mumcuoglu, 2008; Arriaza et al. 2013; Forbes et al. 2013). Mummies also have the potential to preserve the ancient DNA of endoparasites, the proteins secreted by these parasites when alive, and possibly the host antibodies made to fight the infection (Anastasiou and Mitchell, 2013b).

Some endoparasites have the potential to cause anaemia in their human hosts, and we can look for this when we study the skeletal remains of past populations. Examples of parasite infections that often trigger anaemia include malaria, hookworm and schistosomiasis (Garcia, 2009). Anaemia can manifest itself in the skeleton with pitting in the roof of the orbits (cribra orbitalia), on the cranial vault of the skull (porotic hyperostosis) and thickening of the cranial vault (Polo-Cerdá et al. 2001; 
Walker et al. 2009). One study investigated the prevalence of these changes in a site close to Imperial Rome (1st-3rd century AD) and compared it with a 7th century AD population nearby (Salvadei et al. 2001). Cribra orbitalia was present in $60-80 \%$ of children at both sites, highlighting how common anaemia was in Roman period Italy.

\section{PARASITES PRIOR TO THE ROMAN PERIOD}

In order to appreciate the consequences of Romanization following the expansion of the Roman Republic and the subsequent Roman Empire, we need to determine which parasites were present in those people living in the region before the Romans.

In Europe, the inhabitants were hunter-gatherers until around $4000 \mathrm{BC}$ and then started to develop farming in the Neolithic period (4000-2800 BC). The development of metal tools led to the Bronze Age (2800-500 BC) and then Iron Age (700-100 BC). The overlap in dates is due to the gradual spread of these technologies across the continent. In the Neolithic, the intestinal parasites identified were beef or pork tapeworm (Taenia asiatica, Taenia saginata or Taenia solium), bile duct fluke (Opisthorchis sp.), Capillaria sp., E. histolytica dysentery, Fasciola genus liver fluke (Fasciola hepatica), fish tapeworm (Diphyllobothrium sp.), giant kidney worm (Dioctophymidae), hookworm (Ancylostomids), lancet liver fluke (Dicrocoelium sp.), roundworm and whipworm (Bouchet et al. 2003; Anastasiou, 2015). It can be seen that there was a mixture of zoonotic parasites from eating raw or undercooked wild animals (beef/ pork tapeworm, bile duct fluke, capillariosis, fish tapeworm, giant kidney worm, lancet liver fluke) and parasites transmitted by the fecal contamination in villages (Entamoeba dysentery, hookworm, roundworm, whipworm).

In Bronze and Iron Age Europe the parasites found were E. histolytica that can cause dysentery, roundworm, whipworm, lancet liver fluke and so far just two examples of fish tapeworm (Bouchet et al. 2003; Le Bailly and Bouchet, 2013; Anastasiou, 2015). We do have to consider that fewer Bronze and Iron Age archaeological sites have been studied for parasites than is the case for earlier Neolithic or later Roman and medieval periods. However, we do nevertheless have parasites identified from sites in 7 different European countries in the Bronze and Iron Age (Austria, Britain, Czech Republic, Denmark, France, Germany, Poland), so this evidence should reflect the species present reasonably well. It does appear that over time, the number of species affecting people in Europe seems to have decreased from the Neolithic to the Bronze and Iron Age. There seems to have been a shift away from zoonotic parasites contracted from eating raw or undercooked animals, to parasites transmitted by poor personal hygiene (dysentery, roundworm, whipworm). Whether these wild animals were no longer being caught and eaten in the Bronze and Iron Age, or whether the meat was just being cooked better (so killing the parasites), is not entirely clear.

In the Middle East, the ancient parasite evidence before the time of the Romans is more complicated to interpret. This is because human civilization started in the region, where farming, herding and early town and city formation began perhaps 5000 years before they did in Europe (Harris, 1996; Zeder, 2011). Major civilizations developed in Mesopotamia and Egypt several millennia before the expansion of the Roman Empire, and so they were already experiencing the effects of higher population density, the challenges of sanitation and long distance trade with the potential spread of infectious diseases. Intestinal parasites found in the region before Roman times include Fasciola genus liver fluke, fish tapeworm, lancet liver fluke, pinworm, roundworm, schistosomiasis (Schistosomiasis haematobium and Schistosomiasis mansoni), Taenia genus tapeworm, threadworm (Strongyloides stercoralis) and whipworm. Mummification in Egypt also allows the identification of endoparasites not preserved by the skeletonized burials of northern Europe, such as the species that cause dracunculiasis, filariasis, leishmaniasis, malaria, toxoplasmosis and trichinosis (Anastasiou, 2015). It is clear that there was a very broad range of parasites present in the Middle East and North Africa region prior to the arrival of the Romans. It is quite likely this resulted from the higher population density from existing civilizations, the warm climate and the fact that many parasites of humans originated in Africa (Kliks, 1990; Mitchell, 2013).

INTESTINAL PARASITES IN THE ROMAN PERIOD

As the geographical borders of Roman influence varied over time, we will only include evidence from Roman contexts, rather than merely regions that were at some point governed by the Romans. Parasites have been identified from Roman period excavations undertaken in 10 modern countries: Austria, Belgium, Britain, Egypt, France, Germany, Israel, Italy, The Netherlands and Poland. The sites in Italy itself include Rome, Pompeii and Parma. Others are from cesspits, sewer drains, rubbish pits, bog bodies and mummified burials from across Europe and the Mediterranean region.

Human whipworms were found in 8 countries (Table 1), and based on current evidence they seem to have been the most widely spread intestinal parasite in the Roman Empire (Jansen and Over, 1962, 1966; Pike, 1968; Wilson and Rackham, 1976; Jones and Hutchinson, 1991; Rousset et al. 1996; Aspöck et al. 1999; Heirbaut et al. 2011; 
Table 1. Endoparasites found in the Roman period

\begin{tabular}{|c|c|c|}
\hline Species & Country & References \\
\hline \multirow[t]{4}{*}{ Beef/Pork/Asiatic Tapeworm (Taenia sp.) } & Britain & De Rouffignac (1985) \\
\hline & Egypt & Le Bailly et al. (2010) \\
\hline & Germany & Jansen and Over (1962) \\
\hline & Israel & Harter et al. (2004) \\
\hline Capillariosis (Capillaria hepatica) & France & Mowlavi et al. (2014) \\
\hline \multirow{3}{*}{ Dysentery (Entamoeba histolytica) } & Belgium & Le Bailly and Bouchet (2015) \\
\hline & France & Le Bailly and Bouchet (2006) \\
\hline & Italy & Le Bailly and Bouchet (2015) \\
\hline Fasciola Genus Liver Fluke (Fasciola sp.) & Egypt & Harter $(2003)$ \\
\hline \multirow[t]{6}{*}{ Fish tapeworm (Diphyllobothrium latum) } & Austria & Szidat (1944) \\
\hline & Britain & De Rouffignac (1985) \\
\hline & France & Le Bailly and Bouchet (2013) \\
\hline & Germany & Jansen and Over (1962) \\
\hline & Israel & Le Bailly and Bouchet (2013) \\
\hline & Poland & Szidat (1944) \\
\hline \multirow[t]{2}{*}{ Hydatid Calcified Cysts (Echinococcus granulosus) } & France & Mowlavi et al. (2014) \\
\hline & Israel & Zias and Mumcuoglu (1991) \\
\hline \multirow[t]{5}{*}{ Lancet Liver Fluke (Dicrocoelium dendriticum) } & Austria & Aspöck et al. (1999) \\
\hline & Britain & Pike (1968) \\
\hline & France & Le Bailly and Bouchet (2010) \\
\hline & Israel & Zias et al. (2006) \\
\hline & Netherlands & Searcey et al. (2013) \\
\hline Malaria (Plasmodium falciparum) & Egypt & Khairat et al. (2013) \\
\hline \multirow[t]{2}{*}{ Pinworm (Enterobius vermicularis) } & Egypt & Horne $(2002)$ \\
\hline & Israel & Zias et al. (2006) \\
\hline \multirow[t]{6}{*}{ Roundworm (Ascaris lumbricoides) } & Austria & Aspöck et al. (1999) \\
\hline & Britain & Wilson and Rackham (1976) \\
\hline & Germany & Jansen and Over (1962) \\
\hline & Israel & Harter et al. (2004) \\
\hline & Netherlands & Jansen and Over (1966) \\
\hline & Poland & Szidat (1944) \\
\hline Toxoplasmosis (Toxoplasma gondii) & Egypt & Khairat et al. (2013) \\
\hline \multirow[t]{8}{*}{ Whipworm (Trichuris trichiura) } & Austria & Aspöck et al. (1999) \\
\hline & Britain & Wilson and Rackham (1976) \\
\hline & France & Rousset et al. (1996) \\
\hline & Germany & Jansen and Over (1962) \\
\hline & Israel & Witenberg (1961) \\
\hline & Italy & Heirbaut et al. (2011) \\
\hline & Netherlands & Jansen and Over (1966) \\
\hline & Poland & Szidat (1944) \\
\hline
\end{tabular}

Note: (1) not all publications include an image of the eggs described, and in those cases it is possible that the claims may not be accurate. (2) Not all published examples of parasites are included in this table, but one example from each country has been included to show the geographic spread of different species.

Searcey et al. 2013). This is a fecal oral parasite spread by the contamination of food with feces (Garcia, 2009, 332). It could have been spread by the use of unwashed hands to prepare food or by the use of human feces as crop fertilizer.

Human roundworm was the next most widely found parasite species in Roman sites, being identified in 6 countries (Jansen and Over, 1962, 1966; Pike, 1968; Wilson and Rackham, 1976; Jones and Hutchinson, 1991; Rousset et al. 1996; Aspöck et al. 1999; Searcey et al. 2013). Just as was the case for whipworm, roundworm is spread by the fecal contamination of food, and so limited hand hygiene and the manuring of crops with human feces would have facilitated its spread.

The fish tapeworms were also found in 6 countries, namely Austria, Britain, France, Germany,
Israel and Poland (Szidat, 1944; Jansen and Over, 1962; De Rouffignac, 1985; Le Bailly and Bouchet, 2013). They are spread by eating fish of species that spend at least part of their life cycle in fresh water such as rivers or lakes. The parasite eggs of this species will not develop in sea water. If the fish is cooked, this will kill the parasite. Hence, fish tapeworm is typically found in regions where raw, smoked or pickled fish is eaten rather than cooked fish (Garcia, 2009, 354).

Beef/pork/Asiatic tapeworms of humans and dog tapeworm (Echinococcus sp.) eggs all appear similar on microscopy so, these can only be identified to species level using ancient DNA analysis. Eggs have been recovered from Roman Period sites in Britain, Egypt, Germany and Israel (Jansen and Over, 1962; De Rouffignac, 1985; Harter et al. 
2004; Le Bailly et al. 2010).From human feces, its presence indicates that raw or undercooked beef, pork or similar large farm animals were being eaten by the population.

Lancet liver flukes have been found in Austria, Britain, France, Israel and the Netherlands (Pike, 1968; Aspök et al. 1999; Le Bailly and Bouchet, 2010; Searcey et al. 2013). It is generally an infection of animals such as cattle, so if undercooked cow liver is eaten, the eggs of this parasite may end up in human feces, an example of false parasitism. However, Dicrocoelium genus parasites can potentially infect humans and may cause diarrhoea and abdominal bloating. A good example confirming genuine infection of a person in Roman times is the mummy known as Zweeloo woman, dating from 78 to $233 \mathrm{AD}$ (calibrated radiocarbon date). This bog body from the Netherlands was found to have whipworm and roundworm eggs in her intestines, but the eggs of Dicrocoelium dendriticum in the preserved liver (Searcey et al. 2013).

Entamoeba histolytica infection has been detected using ELISA in Roman period samples from latrines and cesspits in Belgium, France and Italy (Gonçalves et al. 2004; Le Bailly and Bouchet, 2006, 2015). Entamoeba histolytica is spread by the drinking of water contaminated by human feces, and can cause outbreaks of dysentery, with bloody diarrhoea, abdominal pain and fevers (Garcia, 2009, 256).

Hydatid disease (Echinococcus granulosus) can be identified in archaeological samples from the calcified cysts found in the abdomen or thorax of human burials. If humans inadvertently consume the eggs of this dog tapeworm, the hydatid cysts develop in the organs of the body. Good examples from the Roman period include calcified hydatid cysts in the burial of a 3 rd-4th century AD adolescent at Amiens in France, and from 1st century AD Jerusalem (Zias and Mumcuoglu, 1991; Mowlavi et al. 2014).

Pinworm eggs have been found in the mummified remains of a teenage girl and an adult male from the Dakleh Oasis in Egypt (30BC-395 AD), and also in latrine soil from the Essenes sect at Qumran in Israel (100 BC-100 AD) (Horne, 2002; Zias et al. 2006). It is spread by fecal contamination of hands or by airborne transmission, and causes intense anal itching at night.

Fasciola genus liver fluke eggs have only been found in one Roman period archaeological context, in Egypt (Harter, 2003). The liver fluke is contracted by humans who eat unwashed water plants grown in locations where farm animals such as sheep and cattle drop their dung (Garcia, 2009, 368).

Capillariosis (Capillaria hepatica) was identified in a burial from France (Mowlavi et al. 2014). Often capillaria eggs in the feces represent false parasitism, when uncooked animal organs had been consumed and passed unchanged in the feces. However, this example was of capillaria eggs embedded in the calcified wall of a hydatid cyst. This demonstrates genuine infection of the individual with capillariosis while they were alive.

Malaria (Plasmodium falciparum) and toxoplasmosis (Toxoplasma gondii) have been identified from their preserved ancient DNA in an Egyptian mummy dating from the third intermediate to Roman Period (Khairat et al. 2013). Malaria is spread by the bite of mosquitos and infection causes fevers, enlarged liver and spleen, and may cause death especially in children (Garcia, 2009, 302). Toxoplasmosis is generally contracted by humans who are in close contact with cats. Since cats were cult animals in ancient Egypt with many being mummified and used as religious offerings (Ikram, 2005), it is possible this exposure to cats put the inhabitants of Egypt at added risk of contracting this parasite compared with other parts of the Roman Empire.

ECTOPARASITES IN THE ROMAN PERIOD

Head lice (Pediculus humanus capitis), body lice (Pediculus humanus corporis), pubic lice (Phthirus pubis), fleas (Pulex irritans) and bed bugs (Cimex lectularius) have been identified at a range of archaeological sites across the world and across time periods (Mumcuoglu, 2008). Ectoparasites from Roman period settlements have been preserved in combs, textiles, tombs and waterlogged soils. While they have not been identified in as many countries as the eggs of intestinal helminths, this seems to reflect the location and interests of those who have been searching for them, and probably does not necessarily indicate their absence from the rest of the Roman Empire.

Head lice and their eggs have been recovered from Roman period wooden combs from the Essene religious sect at Qumran (1st century BC-1st century $\mathrm{AD})$ and the Jewish fortress of Masada (1st century AD), Israel (Mumcuoglu and Zias, 1988). Body lice have also been noted on textiles from Masada dating to the time of Jewish revolt against the Romans (66-73 AD) (Mumcuoglu et al. 2003).

In Britain, large numbers of human fleas have been recovered from sediment layers in Roman Period York (Hall and Kenward, 2015). A pubic louse was recovered from a waterlogged Roman pit dating from the late 1 st to mid-2nd century AD Carlisle (Kenward, 1999). The probable remains of a bed bug were found at Roman Alcester in Warwickshire (Osborne, 1971). One study has assessed the number of ectoparasites in sediments in the same town to compare the Roman period with later times. In York, the concentration of ectoparasites in Roman, Viking and medieval layers were similar across the centuries. For example, human 
head and body lice were found in over 50 archaeological layers and fleas were also routinely detected (Kenward and Hall 1995, 488-91 and 700-3; Hall and Kenward, 2015, 114). This suggests that the Roman habit of washing at the public baths does not seem to have decreased their risk of contracting ectoparasites, compared with Vikings and medieval people who did not use public baths in the same way.

Ectoparasites are also known to spread bacterial infectious diseases amongst humans. For example, the body louse can transmit louse-borne relapsing fever (Borrelia recurrentis), epidemic typhus (Rikkettsia prowazekii) and trench fever (Bartonella qintana) (Gunn and Pitt, 2012, 157). The ancient DNA of these organisms has been extracted from human skeletal remains and from the lice themselves from post-Roman archaeological sites in the past (Raoult et al. 2006; Tran et al. 2011a). It is therefore quite plausible that some Roman period epidemics could have been caused by these bacterial diseases spread by ectoparasites.

Rodent fleas such as Xenopsylla cheopis are thought to have spread bubonic plague (Yersinia pestis) in recent epidemics among humans. When rats die from plague infection, it has been noted that fleas have to transfer to feed from humans rather than starve themselves, so spreading the disease (Schotthoefer et al. 2011; Chouikha and Hinnebusch, 2012; Bobrov et al. 2015). It is not entirely clear which ectoparasites were responsible for spreading plague in past pandemics, since the medieval Black Death still spread across areas such as Scandinavia where rats have been shown to have been either absent or very rare (Hufthammer and Walløe, 2013). The first pandemic of bubonic plague is known as the plague of Justinian, and took place from 541 to 543 AD. It started in the Eastern Roman Empire and then spread across the rest of Europe and the Mediterranean region (Little, 2011). Ancient DNA analysis of human skeletal remains from mass graves dating to this event has determined the genome sequence of the $Y$. pestis strain responsible for the pandemic (Harbeck et al. 2013; Wagner et al. 2014). This has demonstrated that the strain was much earlier on the evolutionary tree than modern plague strains, highlighting considerable evolution of the bacterium over the last 1500 years.

HOW DID THE ROMANS CHANGE PARASITISM ACROSS THE EMPIRE?

If we are going to assess the impact of Romanization across Europe, the Middle East and North Africa, then it is important to compare the evidence for parasites before, during and after the Romans. We have to be careful how we do this, to ensure the conclusions are not misleading due to limitations in the evidence. Some parasites eggs are more fragile than others (such as hookworm and pinworm) and so could have been present in the past despite lack of surviving evidence. In consequence, I will not make claims about the meaning of the presence or absence of these species here. Similarly, some time periods may have been better studied in the past and this might give us more evidence for parasites at the time. In the geographic region under study, there have extremely few studies of parasites in the Paleolithic period, a moderate number in the Neolithic, fewer in the Bronze and Iron Age, a moderate number in the Roman period and a large number in the medieval period. This must be borne in mind when comparing change between the Bronze and Iron Ages with the Roman period, in particular. However, I would argue that we actually have a fairly good idea of the parasites present in the Bronze and Iron Ages for the region that would later become the Roman Empire. There is evidence for the species present in what is now Austria, Britain, Denmark, Egypt, France, Germany, Israel and Poland, and in some countries a number of different Bronze and Iron Age sites have been analysed (Aspöck et al. 1999; Anastasiou, 2015; Anastasiou and Mitchell, 2015). This means that if tough-walled parasite species are absent across all or many of these excavations, it is quite likely to indicate that the species was either rare or absent at that time.

Before the Romans, the Neolithic farmers of Europe and Mediterranean region could be infected with a combination of zoonotic endoparasites such as fish tapeworm, Lancet liver fluke, Fasciola genus liver fluke, bile duct fluke, capillariosis and also parasite species specifically evolved to infect humans such as roundworm, whipworm, hookworm, beef/ pork tapeworm and Entamoeba dysentery protozoa. However, by the time of the Bronze and Iron Age there had already been a shift away from zoonotic parasites so that parasites spread by poor sanitation dominated. Interestingly, this is mirrored by modern nomadic hunter-gatherer societies who settle and become farmers (Dounias and Froment, 2006). Hence, at the time the Romans expanded their empire the dominant parasites in Europe were roundworm, whipworm and Entamoeba protozoa that cause dysentery. Interestingly, Lancet liver fluke was also fairly widespread, suggesting that ants were either accidentally or deliberately consumed. The picture in the Middle East and North Africa at the arrival of the Romans is more complex as ancient civilizations already existed there. In these regions, the range of endemic species was much greater than was the case for Europe.

At the time of the Romans, we see the most widespread and dominant species were roundworm and whipworm. The Romans are credited with spreading the concept of hygienic latrines across the empire, with contoured seats, flushing systems, 
personal hygiene with a sponge on a stick and hand washing (Hobson, 2009; Jansen et al. 2011; Antoniou and Angelakis, 2015; Koloski-Ostrow, 2015). They introduced the culture of person cleanliness with the regular washing in heated public baths (Yegül, 2010). The Romans also introduced legislation whereby human waste from towns and cities would be collected in carts and taken out to the countryside (Taylor, 2015). Modern research has shown that clean drinking water, latrine use and hand washing all decrease the prevalence of geohelminths such as whipworm and roundworm (Zeigelbauer et al. 2012). In view of this, we might expect the prevalence of fecal oral parasites such as whipworm and roundworm to drop in Roman times rather than increase. However, this was not the case and we must ask ourselves why.

One possibility is that the eggs of roundworms and whipworms were spread via the warm communal waters of the Roman bathhouses. In some baths the water was only changed intermittently, and could acquire a scum on the surface from human dirt and cosmetics. Clearly, not all Roman baths were as clean as they might have been (Fagan, 2000; Yegül, 2010). Another possible explanation is that the Romans were known to have used the human feces collected from towns to fertilize crops growing in the fields (Jones, 2012; Taylor, 2015). This has been shown in modern research to increase crop yields (Heinonen-Tanski and vanWijk-Sebesma, 2005). However, unless the feces are composted for many months before being added to the fields, this can result in the spread of viable parasite eggs to the plants grown (Phuc et al. 2006; Jensen et al. 2008). Hence, it may be the use of human feces as crop fertilizer under the Romans that led to an increase in roundworm and whipworm despite their use of sanitation technologies.

Fish tapeworms were found to be surprisingly widespread in the Roman period. This is in contrast to Bronze and Iron Age Europe, where fish tapeworm eggs have only been in France and Germany (Le Bailly and Bouchet, 2013). Bearing in mind there are Bronze and Iron Age sites where parasites have been identified from 7 different countries, the identification of fish tapeworm in just 2 countries suggests the parasite was relatively uncommon at that time. In the Roman period it was identified in 6 countries, which was as many as roundworm. Roundworm and whipworm are perceived by modern researchers to have been more ubiquitous in past farming populations than all other intestinal helminths (Reinhard et al. 2013; Reinhard and Pucu de Araújo, 2014). However, this study has shown for the first time quite how widespread fish tapeworm was at the time of the Romans. It is unlikely that the increase in its detection in Roman period samples is due to chance. It is notable that five of the 6 countries where fish tapeworm was identified were in northern Europe. In northern Europe it was common in the past to smoke, dry, salt or pickle fish to preserve it, and it was often eaten uncooked (Hoffman, 2003; Hagen, 2006, 275-276). The culture of eating uncooked fish may be one element as to why the parasite was quite widespread at this time, but does not explain why there appears to have been an increase between the Bronze/Iron Age and the Roman Period. We must ask ourselves which aspect of Romanization in Europe seems to have triggered this apparent rise in fish tapeworm.

One possibility that could explain a change in fish tapeworm distribution in the Roman period is the Roman enthusiasm for fish sauce, known as garum, liquamen or muria (Cool, 2006, 58). It was not only used as a culinary ingredient, but also as a medicine (Curtis, 1984). Garum was a fermented sauce made from pieces of fish, herbs, salt and flavourings. This sauce was not cooked, but allowed to ferment in the sun (Curtis, 1983). Garum seems to have its origins in the Mediterranean region, but over time was made in northern Europe where fish tapeworm was much more common. Archaeological examples of garum in Roman pottery vessels have been recovered at many sites, and the bones of fish from these pots include both sea fish and fresh water fish (Van Neer et al. 2005; Locker, 2007). Garum was traded right across the empire, ensuring that people living in regions that were not endemic for fish tapeworm would still have been at risk of contracting the parasite (Curtis, 1988; Haley, 1990). It is quite possible that this fermented fish sauce may have acted as a vector for the spread of fish tapeworm and hence contributed to the rise in the archaeological evidence for fish tapeworm in the Roman Empire.

We can see that in Roman times we still have evidence for genuine parasitism of humans by zoonotic parasites that generally affect animals rather than humans today. The $Z_{\text {weeloo woman bog body was }}$ found to have infection by Lancet liver fluke in her liver at the time of death (Searcey et al. 2013). An individual from 3 rd to 4 th century Amiens in France was found to have the eggs of $C$. hepatica entombed in the calcified walls of hydatid cysts, so demonstrating a case of true infective capillariosis during their life (Mowlavi et al. 2014). This illustrates how certain parasites that rarely infect humans today may have caused active infection in past peoples living a less hygienic life style than in modern times.

In Roman times, we have parasite species such as beef and pork tapeworm spread by the consumption of farm animals. We also see the appearance of echinococcosis from dog tapeworm, compatible with the close contact between humans and dogs kept for herding animals or as pets (O'Connor, 2008). In Egypt, the reverence for cats may have facilitated the spread of toxoplasmosis in Roman times there.

It is also interesting to consider the absence of certain parasites in the Roman Empire. We might 
expect to have found the eggs of S. haematobium or $S$. mansoni in Roman latrines in Europe as soldiers, officials and merchants moved between the Middle East and the rest of the empire. There is good archaeological evidence for such migrations from analysis of skull shape, stable isotopes in teeth and written Roman texts (Leach et al. 2009). Schistosomiasis has been identified in Syria and Egypt well before the Roman Period (Anastasiou et al. 2014; Anastasiou and Mitchell, 2015). Both $S$. haematobium and $S$. mansoni have been recovered from medieval latrines in France dating from 1450 to $1550 \mathrm{AD}$, indicating the migration of travellers between France and areas endemic for schistosomiasis (Bouchet and Paicheler, 1995; Bouchet et al. 2002). However, such evidence for migration with parasites has yet to be identified at Roman period sites.

We can get an indication of how parasite infection changed after the Roman Period by comparing excavations of levels from different time periods at the same sites. In Italy, whipworm was the only species of helminth egg recovered from Roman Period Parma. This is in contrast to the 6 species found in the same town during the medieval period (roundworm, whipworm, lancet liver fluke, fish tapeworm, Taenia/Echinococcus sp. and Capillaria sp.) (Bosi et al. 2011; Florenzano et al. 2012). This increase in species found in the same time over this 1000-year period gives an indication of how parasite infections do appear to have been rather different in Roman times compared with later periods. The change may reflect the increasing population size of medieval towns compared with most classical towns in Europe outside Rome itself, as larger populations generally sustain infectious diseases better than small populations. In the medieval period fish tapeworm was even more common than in the Roman Empire, and this may reflect the spread of Christianity and the eating of fish on Fridays and other religious fast days in medieval times (Yeh et al. 2014; Mitchell, 2015b).

\section{MEDICAL HISTORY OF ROMAN PARASITES}

Having demonstrated that a range of endoparasites and ectoparasites infected people living in the Roman Empire, it makes sense to consider what they thought of their parasites, and whether they may have tried to treat them medically.

The core philosophy underpinning Roman beliefs about medicine originated in classical Greece, largely from the Hippocratic corpus of texts. Hippocrates was a medical practitioner born on the island of Kos in the Aegean Sea. He lived during the 5th and 4th centuries BC and the texts he wrote were augmented by those of his students and laid out a new way of thinking about how disease originated. Hippocrates argued that a state of disease could be triggered by an imbalance in the proportions of the four humours (black bile, yellow bile, blood and phlegm) or a corruption of one of these humours (Totelin, 2009; Mann, 2012). The key texts that mention intestinal helminths were in the three works entitled Prognostics, Epidemics and Coan Prognoses (Hippocrates, 1839; Trompoukis et al. 2007).

The leading Roman period medical practitioner was Aelius Galenus, who lived from c.130 AD to c.210AD. Galen was a physician to the Roman Emperors Marcus Aurelius (ruled 161-180 AD), Commodus (ruled 180-192 AD) and Septimus Severus (ruled 193-211 AD), and wrote a large collection of medical texts (Johnston, 2006; Hankinson, 2008; Mattern, 2013). He followed the humoural theory of Hippocrates, and also adopted his basic classification of helminths. Galen described three groups of intestinal worms, named lumbrici lati, teretes and ascarides. We do have to be careful when using ancient texts to come to a modern diagnosis of past disease, as there are many factors that might complicate a seemingly obvious description (Mitchell, 2011). However, from these descriptions it has been proposed that these terms probably equate to Taenia genus tapeworms, roundworm and pinworm, respectively (Jirsa and Winiwarter, 2010). Galen believed that helminths were formed from spontaneous generation in putrified matter under the effect of heat. He recommended treatment with dietary modification, bloodletting and medicines that were believed to have a cooling and drying effect, in order to return the humoural balance to normal. Galen's beliefs as to the origin and treatment of intestinal parasites were to become the accepted view in Europe and the Middle East for over 1000 years, until the time of the Renaissance and the Enlightenment.

While medical practitioners attempted to treat certain types of parasite with medicines, we have archaeological evidence that people also tried to physically remove head lice with special combs. In Roman Period Judea (Israel), two-sided combs of wood, bone or ivory have been excavated. On one side the teeth of the comb were well spaced, presumably in order to comb the hair. On the other side the teeth were placed very close together, in order to remove the head lice and eggs. Indeed both lice and their eggs have been noted on microscopy, caught between the fine teeth (Mumcuoglu and Zias, 1988).

\section{Concluding remarks}

We can see that 12 species of endoparasite and 5 species of ectoparasite have been identified in Roman Period archaeological sites. Roman technology such as flushing latrines, clean piped water, sewers and drains, hand washing and bath houses does not seem to have protected them from 
contracting either intestinal parasites or ectoparasites. Using human feces as crop fertilizer may explain why roundworms and whipworms were so common in the Roman period. Certain ectoparasites may well have spread infectious diseases, and one likely example to have been spread by flea bite was the Plague of Justinian, now known to have been an early strain of bubonic plague.

One unexpected finding from this analysis was that fish tapeworms seem to have been fairly widespread in Roman Period Europe, in contrast to the evidence from the Bronze and Iron Age. After considering possible explanations, it seems plausible that the Roman enthusiasm for the fermented fish sauce known as garum may have acted as a method where fish tapeworm eggs could have been transported large distances across the empire and then be consumed without being subjected to cooking.

We have presented archaeological evidence for genuine infection by parasites that rarely cause disease in people living today. Examples of lancet liver fluke and capillariosis that were not false parasitism suggest that the way of life under the Romans may have facilitated the invasion of human tissues by these organisms more easily than do modern lifestyles.

Roman doctors believed intestinal worms were formed by spontaneous generation from putrefied matter under the effect of heat. They tried to treat them by rebalancing the four bodily humours with dietary modification, bloodletting and medicines. There is also evidence for special delousing combs to strip head lice from the hair, and delousing may have been a daily routine for many people living across the Roman Empire.

\section{FINANCIAL SUPPORT}

This research received no specific grant from any funding agency, commercial or not-for-profit sectors.

\section{REFERENCES}

Anastasiou, E. (2015). Parasites in European populations from prehistory to the industrial revolution. In Sanitation, Latrines and Intestinal Parasites in Past Populations (ed. Mitchell, P. D.), pp. 203-217. Ashgate, Farnham, UK. Anastasiou, E. and Mitchell, P.D. (2013a). Simplifying the process of extracting parasitic worm eggs from cesspool and latrine sediments: a trial comparing the efficacy of widely used techniques for dissaggregation. International Fournal of Paleopathology 3, 204-207.

Anastasiou, E. and Mitchell, P. D. (2013b). Paleopathology and genes: investigating the genetics of infectious diseases in excavated human skeletal remains and mummies from past populations. Gene 528, 33-40.

Anastasiou, E. and Mitchell, P. D. (2015). Human intestinal parasites in Africa and the Middle East prior to 1500. In Sanitation, Latrines and Intestinal Parasites in Past Populations (ed. Mitchell, P. D.), pp. 121-147. Ashgate, Farnham, UK.

Anastasiou, E., Lorentz, K. O., Stein, G. J. and Mitchell, P. D. (2014). Prehistoric schistosomiasis parasite found in the Middle East. Lancet Infectious Diseases 14, 553-554.

Antoniou, G. P. and Angelakis, A. N. (2015). Latrines and wastewater sanitation technologies in ancient Greece. In Sanitation, Latrines and Intestinal Parasites in Past Populations (ed. Mitchell, P. D.), pp. 41-68. Ashgate, Farnham, UK.
Araújo, A., Reinhard, K. and Ferreira, L. F. (2015). Paleoparasitology human parasites in ancient material. Advances in Parasitology 90, 349-387. Arriaza, B., Standen, V., Reinhard, K., Araújo, A., Heukelbach, J. and Dittmar, K. (2013). On head lice and social interaction in archaic Andean coastal populations. International Fournal of Paleopathology 3, 257-268.

Aspöck, H., Auer, H. and Picher, O. (1999). Parasites and parasitic diseases in prehistoric human populations in central Europe. Helminthologia 36, 139-145.

Baeten, J., Marinova, E., De Laet, V., Degryse, P., De Vos, D. and Waelkens, M. (2012). Faecal biomarker and archaeobotanical analyses of sediments from a public latrine shed new light on ruralisation in Sagalassos, Turkey. Fournal of Archaeological Science 39, 1143-1159.

Bobrov, A. G., Kirillina, O., Vadyvaloo, V., Koestler, B. J., Hinz, A. K., Mack, D., Waters, C. M. and Perry, R. D. (2015). The Yersinia pestis $\mathrm{HmsCDE}$ regulatory system is essential for blockage of the oriental rat flea (Xenopsylla cheopis), a classic plague vector. Environmental Microbiology 17, 947-959.

Bosi, G., Mazzanti, M. B., Florenzano, A., N'siala, I. M., Pederzoli, A., Rinaldi, P., Torri, P. and Mercuri, A. M. (2011) Seeds/fruits, pollen and parasite remains as evidence of site function: piazza Garibaldi - Parma (N Italy) in Roman and Mediaeval times. Fournal of Archaeolgical Science 38, 1621-1633.

Bouchet, F. and Paicheler, J. C. (1995). Paleoparasitologie: présumption d'un cas de bilharziose au XVe siècle à Montbéliard (Doubs, France). Comptes Rendus de l'Academie des Sciences 318, 811-814.

Bouchet, F., Harter, S., Paicheler, J. C., Araújo, A. and Ferreira, L. F. (2002). First recovery of Schistosoma mansoni eggs from a latrine in Europe (15th-16th centuries). Fournal of Parasitology 88, 404-405.

Bouchet, F., Harter, S. and Le Bailly, M. (2003). The state of the art of palaeoparasitology research in the Old World. Memorias do Instituto Oswaldo Cruz 98(Suppl. 1), 92-102.

Brownworth, L. (2009). Lost to the West: The Forgotten Byzantine Empire that Rescued Western Civilization. Crown Publishers, New York, USA.

Chouikha, I. and Hinnebusch, B. J. (2012). Yersinia-flea interactions and the evolution of the arthropod-borne transmission route of plague. Current Opinion in Microbiology 15, 239-246.

Cool, H. E. M. (2006). Eating and Drinking in Roman Britain. Cambridge University Press, Cambridge, UK.

Curtis, R. I. (1983). In defense of Garum. Classical fournal 78, 232-240. Curtis, R. I. (1984). Salted fish products in ancient medicine. Fournal of the History of Medicine and Allied Sciences 39, 430-445.

Curtis, R. I. (1988). Spanish trade in salted fish products in the 1st and 2nd centuries AD. International Fournal of Nautical Archaeology and Underwater Exploration 17, 205-210.

Da Rocha, G. C., Harter, S., Le Bailly, M., Araújo, A., Ferreira, L. F., Serra-Freire, M. and Bouchet, F. (2006). Paleoparasitological remains revealed by seven historic contexts from 'Place d'Armes', Namur, Belgium. Memórias do Instituto Oswaldo Cruz 101(Suppl. 2), 43-52.

De Rouffignac, C. (1985). Parasite egg survival and identification from Hibernia Warf, Southwark. London Archaeologist 5, 103-105.

Dounias, E. and Froment, A. (2006). When forest-based hunter-gatherers become sedentary: consequences for diet and health. Unasylva $\mathbf{5 7}$, 26-33.

Fagan, G. G. (2000). Hygiene conditions in Roman public baths. In Cura Aquarum in Sicilia: Proceedings of the 10th International Congress on the History of Water Management and Hydraulic Engineering in the Mediterranean Region (ed. Jansen, G. C. M.), pp. 281-286. Peeters, Leiden, Netherlands.

Florenzano, A., Mercuri, A. M., Pederzoli, A., Torri, P., Bosi, G., Olmi, L., Rinaldi, R. and Mazzanti, M. B. (2012). The significance of intestinal parasite remains in pollen samples from medieval pits in the Piazza Garibaldi of Parma, Emilia Romagna, Northern Italy. Geoarchaeology 27, 34-47.

Forbes, V., Dussault, F. and Bain, A. (2013). Contributions of ectoparasite studies in archaeology with two examples from the North Atlantic region. International fournal of Paleopathology 3, 158-164.

Frías, L., Leles, D. and Araújo, A. (2013). Studies on protozoa in ancient remains - a review. Memorias do Instituto Oswaldo Cruz 108, 1-12.

Garcia, L. S. (2009). Practical Guide to Diagnostic Parasitology. 2nd Edn. ASM Press, Washington, USA.

Gonçalves, C. L.M., da Silva, V.L., de Andrade, C. M., Reinhard, K., Da Rocha, G. C., Le Bailly, M., Bouchet, F., Ferreira, L. F. and Araújo, A. (2004). Amoebiasis distribution in the past: first steps using an immunoassay technique. Transactions of the Royal Society of Tropical Medicine and Hygiene 98, 88-91.

Gonçalves, M. L. C., Araújo, A., Duarte, R., Pereira da Silva, J.P., Reinhard, K., Bouchet, F. and Ferreira, L.F. (2002). Detection of Giardia duodenalis antigen in coprolites using a commercially available 
enzyme-linked immunosorbent assay. Transactions of the Royal Society of Tropical Medicine and Hygiene 96, 640-643.

Gunn, A. and Pitt, S. J. (2012). Parasitology: an Integrated Approach. Wiley-Blackwell, Chichester, UK

Hagen, A. (2006). Anglo-Saxon Food and Drink: Production, Processing, Distribution and Consumption. Anglo-Saxon Books, Hockwold Cum Wilton, UK

Haley, E. W. (1990). The fish sauce trader L. Iunius Puteolanus. Zeitschrift für Papyrologie und Epigraphik 80, 72-78.

Hall, A. R. and Kenward, H. K. (2015). Sewers, cesspits and middens: a survey of the evidence for 2000 years of waste disposal in York, UK. In Sanitation, Latrines and Intestinal Parasites in Past Populations (ed. Mitchell, P. D.), pp. 99-119. Ashgate, Farnham, UK

Handley, M. A. (2011). Dying on Foreign Shores: Travel and Mobility in the Late-Antique West. Journal of Roman Archaeology, Portsmouth, USA. Hankinson, R. J. (2008). The Cambridge Companion to Galen. Cambridge University Press, Cambridge, UK

Harbeck, M., Seifert, L., Hänsch, S., Wagner, D. W., Birdsell, D., Parise, K. L., Wiechmann, I., Grupe, G., Thomas, A., Keim, P., Zöller, L., Bramanti, B., Riehm, J. M. and Scholz, H.C. (2013). Yersinia pestis DNA from skeletal remains from the 6th century AD reveals insights into Justinianic Plague. PLoS Pathogens 9, e1003349.

Harris, D. R. (ed.) (1996). The Origins and Spread of Agriculture and Pastoralism in Eurasia: Crops, Fields, Flocks and Herds. UCL Press, London, UK.

Harter, S. (2003). Implication de la Paléoparasitologie dans l'Etude des Populations Anciennes de la Vallée du Nil et du Proche-Orient: Etudes de Cas. Ph.D. thesis. Université de Riems Champagne-Ardenne, France. Harter, S., Bouchet, F., Mumcuoglu, K. Y. and Zias, J. (2004). Toilet practices among members of the Dead Sea Scroll sect at Qumran (100 BC68 AD). Revue de Qumran 21, 579-584.

Heinonen-Tanski, H. and van Wijk-Sebesma, C. (2005). Human excreta for plant production. Bioresource Technology 96, 403-411.

Heirbaut, E., Jones, A. K. G. and Wheeler, W. (2011). Archaeometry: methods and analysis. In Roman Toilets: Their Archaeology and Cultural History (ed. Jansen, G. C. M., Koloski-Ostrow, A. O. and Moormann, E. M.), pp. 7-20. Peeters, Leuven, Belgium.

Hippocrates (1839-61). Oevres Complètes (ed. Littré, M. P. E.) Vol. 10. Paris, France.

Hobson, B. (2009). Latrinae et Foricae: Toilets in the Roman World. Duckworth, London, UK.

Hoffman, R. C. (2003). A brief history of aquatic resource use in medieval Europe. Helgoland Marine Research 59, 22-30.

Horne, P. D. (2002). First evidence of Enterobiasis in ancient Egypt. Fournal of Parasitology 88, 1019-1021.

Hufthammer, A. K. and Walløe, L. (2013). Rats cannot have been intermediate hosts for Yersinia pestis during medieval plague epidemics in northern Europe. Fournal of Archaeological Science 40, 1752-1759.

Ikram, S. (2005). Divine Creatures: Animal Mummies in Ancient Egypt. American University of Cairo, Cairo, Egypt

Jaeger, L. H. and Iniguez, A. M. (2014). Molecular paleoparasitological hybridization approach as effective tool for diagnosing human intestinal parasites from scarce archaeological remains. PLoS ONE 9, e105910.

Jansen, G. C. M., Koloski-Ostrow, A. O. and Moorman, E. M. (eds.) (2011) Roman Toilets: Their Archaeology and Cultural History. Peeters Press, Leuven, Belgium.

Jansen, J. and Over, H. J. (1962). Het voorkomen van parasieten in terpmateriaal uit Noordwest Duitsland. Tijdschr Diergeneesk 87, 1377-1379.

Jansen, J. and Over, H. J. (1966). Observations on helminth infections in a Roman army camp. In Proceedings of the 1st International Congress of Parasitology, Roma, Italy, 1964 (ed. Corradetti, A.) p. 791. Pergamon, Oxford, UK.

Jensen, P. K., Phuc, P.D., Knudsen, L. G., Dalsgaard, A. and Konradsen, F. (2008). Hygiene versus fertiliser: the use of human excreta in agriculture - a Vietnamese example. International fournal of Hygiene and Environmental Health 211, 432-439.

Jirsa, F. and Winiwarter, V. (2010). Eingeweidewürmer in Galens Schriften [Intestinal helminths in the works of Galen]. Wiener Klinische Wochenschrift 122(3 Suppl.), 14-18.

Johnston, I. (2006). Galen on Diseases and Symptoms. Cambridge University Press, Cambridge, UK.

Jones, A. K. G. and Hutchinson, A. R. (1991). The parasitological evidence. In The Structural Sequence and Environmental Remains from Castle Street, Carlisle: Excavations 1981-2 (ed. McCarthy, M. R.), Research Series no. 5, Cumberland and Westmorland Antiquarian and Archaeological Society, Kendal, UK.

Jones, R. (ed.) (2012). Manure Matters: Historical, Archaeological and Ethnographic Perspectives. Ashgate, Farnham, UK.
Kenward, H. K. (1999). Pubic lice (Pthirus pubis L.) were present in Roman and Medieval Britain. Antiquity 73, 911-915.

Kenward, H. K. and Hall, A. R. (1995). Biological Evidence from 16-22 Coppergate. Archaeology of York Series no.14/7. Council for British Archaeology, York, UK.

Kershaw, S. (2013). A Brief History of the Roman Empire. Robinson, London, UK.

Khairat, R., Ball, M., Chang, C.-C. H., Bianucci, R., Nerlich, A. G., Trautmann, M., Ismail, S., Shanab, G. M. L., Karim, A. M., Gad, Y.Z. and Pusch, C. M. (2013). First insights into the metagenome of Egyptian mummies using next-generation sequencing. Fournal of Applied Genetics 54, 309-325.

Kliks, M. M. (1990). Helminths as heirlooms and souvenirs: a review of New World paleoparasitology. Parasitology Today 6, 93-100.

Koloski-Ostrow, A. O. (2015). The Archaeology of Sanitation in Roman Italy: Toilets, Sewers, and Water Systems. University of North Carolina Press, Chapel Hill, USA.

Leach, S., Lewis, M., Chenery, C., Müldner, G. and Eckardt, H. (2009). Migration and diversity in Roman Britain: a multidisciplinary approach to the identification of immigrants in Roman York, England. American Fournal of Physical Anthropology 140, 546-561.

Le Bailly, M. and Bouchet, F. (2006). Paléoparasitologie et immunologie: l'exemple d'Entamoeba histolytica. Archéosciences Revue d'Archaeometrie 30, 129-135

Le Bailly, M. and Bouchet, F. (2010). Ancient dicrocoeliasis: occurrence, distribution and migration. Acta Tropica 115, 175-180.

Le Bailly, M. and Bouchet, F. (2013). Diphyllobothrium in the past: review and new records. International fournal of Paleopathology 3, 182-187.

Le Bailly, M. and Bouchet, F. (2015). A first attempt to retrace the history of dysentery caused by Entamoeba histolytica. In Sanitation, Latrines and Intestinal Parasites in Past Populations (ed. Mitchell, P. D.), pp. 219-228. Ashgate, Farnham, UK.

Le Bailly, M., Mouze, S., Rocha, G. C. D., Heim, J.-L., Lichtenberg, R., Dunand, F. and Bouchet, F. (2010). Identification of Taenia sp. in a mummy from a Christian necropolis in El-Deir, Oasis of Kharga, ancient Egypt. Fournal of Parasitology 96, 213-215.

Leles, D., Araújo, A., Ferreira, L.F., Vicente, A.C.P. and Iñiguez, A. M. (2008). Molecular paleoparasitological diagnosis of Ascaris sp. from coprolites: new scenery of Ascariasis in pre-Columbian South America times. Memorias do Instituto Oswaldo Cruz 103, 106-108. Lintott, A. (2000). The Roman Republic. Sutton, Stroud, UK. Little, L. K. (2011). Plague historians in lab coats. Past and Present 213, 267-290.

Locker, A. (2007). In piscibus diversis; the bone evidence for fish consumption in Roman Britain. Britannia 38, 141-180.

Mann, J. E. (2012). Hippocrates, On the Art of Medicine. Brill, Leiden, The Netherlands.

Mattern, S. P. (2013). The Prince of Medicine: Galen in the Roman Empire. Oxford University Press, Oxford, UK.

Mitchell, P.D. (2011). Retrospective diagnosis, and the use of historical texts for investigating disease in the past. International Fournal of Paleopathology 1, 81-88.

Mitchell, P.D. (2013). The origins of human parasites: exploring the evidence for endoparasitism throughout human evolution. International Fournal of Paleopathology 3, 191-198.

Mitchell, P.D. (2015a). Assessing the impact of sanitation upon health in early human populations from hunter-gatherers to ancient civilizations, using theoretical modelling. In Sanitation, Latrines and Intestinal Parasites in Past Populations (ed. Mitchell, P. D.) pp. 5-17. Ashgate, Farnham, UK.

Mitchell, P.D. (2015b). Human parasites in medieval Europe: lifestyle, sanitation and medical treatment. Advances in Parasitology 90, 389-420.

Mowlavi, G., Kacki, S., Dupouy-Camet, J., Mobedi, I., Makki, M., Harandi, M. F. and Naddaf, S. R. (2014). Probable hepatic capillariosis and hydatidosis in an adolescent from the late Roman period buried in Amiens (France). Parasite 21, 9.

Mumcuoglu, K. Y. (2008). Human lice: pediculus and pthirus. In Paleomicrobiology: Past Human Infections (ed. Raoult, D. and Drancourt, M.), pp. 215-222. Springer-Verlag, Berlin, Germany.

Mumcuoglu, K. Y. and Zias, J. (1988). Head lice, Pediculus humanus capitis (Anoplura: Pediculidae) from hair combs excavated in Israel and dated from the first century BC to the eighth century AD. Fournal of Medical Entomology 25, 545-547.

Mumcuoglu, K. Y., Zias, J., Tarshis, M., Lavi, M. and Stiebe, G. D. (2003). Body louse remains in textiles excavated at Masada, Israel. Fournal of Medical Entomology 40, 585-587.

O'Connor, T.P. (2008). Pets and pests in Roman and medieval Britain. Mammal Review 22, 107-113. 
Oh, C.S., Seo, M., Chai, J. Y., Lee, S. J., Kim, M. J., Park, J. B. and Shin, D. H. (2010). Amplification and sequencing of Trichuris trichiura ancient DNA extracted from archaeological sediments. Fournal of Archaeological Science 37, 1269-1273.

Osborne, P. J. (1971). An insect fauna from the Roman site at Alcester, Warwickshire. Britannia 2, 156-165.

Phuc, P.D., Konradsen, F., Phuong, P.T., Cam, P.D. and Dalsgaard, A. (2006). Practice of using human excreta as fertilizer and implications for health in Nghean Province, Vietnam. Southeast Asian Fournal of Tropical Medicine and Public Health 37, 222-229.

Pike, A. W. (1968). The recovery of parasite eggs from ancient cesspit and latrine deposits: an approach to the study of early parasite infections. In Diseases in Antiquity (ed. Brothwell, D. and Sandison, A. T.), pp. 184 188. C.C. Thomas, Springfield, UK.

Pitts, M. and Versluys, M. J. (2015). Globalisation and the Roman World: World History, Connectivity and Material Culture. Cambridge University Press, New York.

Polo-Cerdá, M., Miquel-Feucht, M. and Villalaín-Blanco, J. D. (2001). Experimental cribra orbitalia in wistar rats: an etiopathogenic model of porotic hyperostosis and other porotic phenomena. In Proceedings of the XIIIth European Meeting of the Paleopathology Association, Chieti, Italy (ed. La Verghetta, M. and Capasso, L.), pp. 253-259. Edigrafital S. p. a., Teramo, Italy.

Raoult, D., Dutour, O., Houhamdi, L., Jankauskas, R., Fournier, P. E., Ardagna, Y., Drancourt, M., Signoli, M., Dang La, V., Macia, Y. and Aboudharam, G. (2006). Evidence for louse-transmitted diseases in soldiers of Napoleon's Grand Army in Vilnius. Fournal of Infectious Diseases 193, 112-120.

Rácz, E. E., Pucu de Aráujo, E., Jensen, E., Mostek, C., Morrow, J. J., Van Hove, M. L., Bianucci, R., Willems, D., Heller, F., Aráujo, A. and Reinhard, K. J. (2015). Parasitology in an archaeological context: analysis of medieval burials in Nivelles, Belgium. Fournal of Archaeological Science 53, 304-315.

Reinhard, K. and Pucu de Araújo, E. (2014). Comparative parasitological perspectives on epidemiological transitions: the Americas and Europe. In Modern Environments and Human Health: Revisiting the Second Epidemiological Transition (ed. Zuckerman, M. K.), pp. 311-326. Wiley-Blackwell, Chichester, UK.

Reinhard, K., Confalonieri, U., Ferreira, L.F., Herrmann, B. and Araújo, A. (1986). Recovery of parasite remains from coprolites and latrines: aspects of paleoparasitological technique. Homo 37, 217-239. Reinhard, K., Ferreira, L.F., Bouchet, F., Sianto, L., Dutra, J., Iñiguez, A. M., Leles, D., Le Bailly, M., Fugassa, M., Pucu, E. and Araújo, A. (2013). Food, parasites, and epidemiological transitions: a broad perspective. International fournal of Paleopathology 86, 1-8.

Rousset, J. J., Heron, C. and Metrot, P. (1996). Human helminthiasis at the Gauls. Histoire des Sciences Medicales 30, 41-46.

Salvadei, L., Ricci, F. and Manzi, G. (2001). Porotic hyperostosis as a marker of health and nutritional conditions during childhood: studies at the transition between Imperial Rome and the early Middle Ages. American Fournal of Human Biology 13, 709-717.

Schotthoefer, A. M., Bearden, S. W., Holmes, J. L., Vetter, S. M., Montenieri, J. A., Williams, S. K., Graham, C. B., Woods, M. E., Eisen, R. J. and Gage, K. L. (2011). Effects of temperature on the transmission of Yersinia pestis by the flea, Xenopsylla cheopis, in the late phase period. Parasites and Vectors 4, 191

Searcey, N., Reinhard, K. J., Egarter-Vig1, E., Maixner, F., Piombino-Mascali, D., Zink, A. R., van der Sanden, W., Gardner, S. L. and Bianucci, R. (2013). Parasitism of the Zweeloo woman: dicrocoeliasis evidenced in a Roman period bog mummy. International Fournal of Paleopathology 3, 224-228.
Shillito, L.-M., Bull, I. D., Matthew, W., Almond, M. J., Williams, J. M. and Evershed, R. P. (2011). Biomolecular and micromorphological analysis of suspected faecal deposits at Neolithic Catalhöyük, Turkey. Fournal of Archaeological Science 38, 1869-1877.

Stathakopoulos, D. C. (2014). A Short History of the Byzantine Empire. I. B. Tauris, London, UK.

Szidat, L. (1944). Über die erhaltungsfähigkeit von helmintheneiern in vor- und frühgeschichtlichen moorleichen. Zeitschrift für Parasitenkunde 13, 265-274.

Taylor, C. (2015). A tale of two cities: the efficacy of ancient and medieval sanitation methods. In Sanitation, Latrines and Intestinal Parasites in Past Populations (ed. Mitchell, P. D.), pp. 69-97. Ashgate, Farnham, UK. Totelin, L. M. V. (2009). Hippocratic Recipes: Oral and Written Transmission of Pharmacological Knowledge in Fifth-and Fourth-Century Greece. Brill, Leiden, The Netherlands.

Tran, T. -N. -N., Forestier, C. L., Drancourt, D., Raoult, D. and Aboudharam, G. (2011a). Co-detection of Bartonella quintana and Yersinia pestis in an 11th-15th century burial site in Bondy, France. American Fournal of Physical Anthropology 145, 489-494.

Trompoukis, C., German, C. and Falagas, M. E. (2007). From the roots of parasitology: Hippocrates' first scientific observations in helminthology. Fournal of Parasitology 93, 970-972.

Van Neer, W., Wouters, W., Ervynck, A. and Maes, J. (2005). New evidence from a Roman context in Belgium for fish sauce locally produced in northern Gaul. Archaeofauna 14, 171-182.

Wagner, D. M., Klunk, J., Harbeck, M., Devault, A. Waglechner, N., Sahl, J. W., Enk, J., Birdsel, D. N., Kuch, M. Lumibao, C., Poinar, D., Pearson, T., Fourment, M., Golding, B., Riehm, J. M., Earn, D. J., DeWitte, S., Rouillard, J. M., Grupe, G., Wiechmann, I., Bliska, J. B., Keim, P.S., Scholz, H. C., Holmes, E. C. and Poinar, H. (2014). Yersinia pestis and the Plague of Justinian 541-543 AD: a genomic analysis. Lancet Infectious Diseases, 14, 319-326.

Walker, P. L., Bathurst, R., Richman, R., Gjerdrum, T. and Andrushko, V. A. (2009). The causes of porotic hyperostosis and cribra orbitalia: a re-appraisal of the iron deficiency anaemia hypothesis. American Fournal of Physical Anthropology 139, 109-125.

Warnock, P. J. and Reinhard, K. J. (1992). Methods for extracting pollen and parasite eggs from latrine soils. Fournal of Archaeological Science 19, 261-264

Wilson, A. and Rackham, D. J. (1976). Parasite eggs. In The Environmental Evidence from the Church Street Roman Sewer System (ed. Buckland, P. C.) The Archaeology of York Series no.14(1), pp. 32-33. York Archaeological Trust, York, UK.

Witenberg, G. (1961). Human parasites in archaeological findings. Bulletin of the Israel Exploration Society 25, 86.

Yegül, F. K. (2010). Bathing in the Roman World. Cambridge University Press, Cambridge, UK.

Yeh, H. -Y., Pluskowski, A., Kalējs, U. and Mitchell, P.D. (2014) Intestinal parasites in a mid-14th century latrine from Riga, Latvia: fish tapeworm and the consumption of uncooked fish in the medieval eastern Baltic region. Fournal of Archaeological Science 49, 83-89.

Zeder, M. A. (2011). The origins of agriculture in the Near East. Current Anthropology 52, S221-S235.

Zeigelbauer, K., Speich, B., Mäusezahl, D., Bos, R., Keiser, J. and Utzinger, J. (2012). Effect of sanitation on soil-transmitting helminth infection: systematic review and meta-analysis. PLoS Medicine 9, e1001162. Zias, J. and Mumcuoglu, K. Y. (1991). Case reports on paleopathology: calcified hydatid cysts. Paleopathology Newsletter 73, 7-8

Zias, J., Tabor, J. D. and Harter-Lailheugue, S. (2006). Toilets at Qumran, the Essenes, and the scrolls: new anthropological data and old theories. Revue de Qumran 22, 631-640. 